\title{
Urgences
}

\section{nous n'aurons pas...}

\section{Paul Chanel Malenfant}

Numéro 15, octobre 1986

\section{Épigraphiques}

URI : https://id.erudit.org/iderudit/025295ar

DOI : https://doi.org/10.7202/025295ar

Aller au sommaire du numéro

\section{Éditeur(s)}

Urgences

\section{ISSN}

0226-9554 (imprimé)

1927-3924 (numérique)

Découvrir la revue

\section{Citer ce document}

Malenfant, P. C. (1986). nous n'aurons pas... Urgences, (15), 28-28.

https://doi.org/10.7202/025295ar d'utilisation que vous pouvez consulter en ligne.

https://apropos.erudit.org/fr/usagers/politique-dutilisation/ 


\section{Paul Chanel Malenfant}

S'y trompent et fuient, croyant, jalouses, une dernière fois à la Tragédie; s'en font à nouveau le Deuil et mère, dans ce profond fumoir, parle la dernière.

Normand de Bellefeuille: Miser

nous n'aurons pas dressé le monument mais la musique n'a rien de funéraire ni la passerelle au-dessus de l'eau je dis le filé de la voix aux rouges gorges de la mère cela ce souffle ce vin cette allure souple des muscles sous la pensée une femme vacille de sonorités et sombre sonore et polonaise et chante dirait-elle la mort comme une bouche en l'air suspendue ou berceau de terrain vague tu entends des serpentins de phrases partitions écritures ou l'espace staccato se lisse flûte et orchidée de frissons au bord de la mer sur une chaise devenue folle et chantre de seins grégoriens voix de plume et voie lactée toute écho elle remue de murmures et hurlements de cheveux rien de cris et tous effets de langues glottes et salives de prose elle s'évide stabat et stances et pleure à mourir la mort du père nu et muet qui derrière elle laisse le fils 